\title{
A FENNTARTHATÓ VÁLLALKOZÁSOK ELŐSEGÍTÉSE
}

A cikk magyar szempontból, a magyar gazdaság és vállalatszervezet speciális vonásai alapján értelmezi a fenntartható vállalkozást és környezetét, és von le elméleti és gazdaságpolitikai következtetéseket. A szerzố dolgozatában fóleg a kis- és közepes vállalkozások (KKV) fenntarthatóságával foglalkozik. A hazai tapasztalatok hasznosak lehetnek sok olyan ország számára, amelyek a gazdasági fejlettségi szint, a vállalatszervezet sajátosságai, a fejlő́déstörténeti örökség stb. tekintetében hasonlítanak Magyarországra.'

Kulcsszavak: fenntartható fejlódés, fenntartható vállalkozásfejlesztés, kis- és közepes vállalkozások (KKV), Magyarország

Az utóbbi években a fenntarthatóság fogalmát mindinkább kiterjesztik a vállalkozásokra. A hagyományos megközelítés a vállalkozásokat lineáris input-output kapcsolatokként értelmezi, amelyek kizárólagos célja a rövid távú gazdasági érték maximalizálása. A fenntartható vállalkozásfejlesztés integrált megközelítése holisztikus és hosszabb távú perspektívát tartalmaz. A fenntartható vállalkozások fogalma vállalkozásokat és különbözó érintettjeit, így a tulajdonosokat, a munkaadókat, a munkavállalókat és a fogyasztókat, valamint a beszállítókkal, a kormányokkal és a szélesebb közösségekkel fenntartott kapcsolatokat foglalja magába².

A fenntarthatóság több szintje különböztethetố meg. Ezek közül a mikro- és a makroszintet emeljük ki. A mikroszint a vállalaton belüli viszonyokat, illetve a vállalat és a közvetlen környezete közötti kapcsolatokat (beszállítók, ügyfelek stb.) jelöli. A makroszintet a vállalkozások verseny- és szabályozási környezete alkotja. A szabályozási környezetbe a szakpolitikákat és az egyes vállalkozásokat érintő konkrét szabályozókat és jogszabályi környezetet egyaránt beleértik.

E tanulmány célja a fenntartható vállalkozás fogalmának értelmezése, alkalmazhatóságának vizsgálata általában és a konkrét magyarországi feltételek között. Az írás a Nemzetközi Munkaügyi Szervezet The promotion of sustainable enterprises címú hivatkozott tanulmányának terminológiáját, definícióit, fóbb megállapításait és következtetéseit tekinti mérvadónak. A gazdag anyagból azonban csak a magyar szempont- ból releváns fejezetekhez kapcsolódik. A tanulmány emellett az Európai Unióban született elemzésekre, valamint nemzetközi tapasztalatokra és analógiákra is épít, természetesen a hazai specifikus sajátosságok figyelembevételével.

A fenntartható vállalat fogalma a munkavállalók, a tulajdonosok, a menedzserek és az állam számára egyaránt tartalmaz követelményeket. Az ILO tanulmánya az összes érintettel foglalkozik. Ami a menedzsereket és a tulajdonosokat illeti, figyelmet érdemel, hogy az Európai Unióban mind nagyobb mértékben terjed a tartós életképesség igazolásának követelménye. A tartós életképesség fogalmába a minôségirányítás és a környezetközpontú vállalatirányítási rendszerek mellett beletartozik a vállalat gazdasági szempontból vett életképessége is. Eszerint az EU-ban bejegyzett vállalatok olyan partnerekkel kívánnak tartós üzleti kapcsolatokat kiépíteni, amelyek nem túnnek el egyik napról a másikra a piacról. A tartós életképességüket igazolni tudó vállalkozások előnyben részesítése a vállalatok közötti együttmúködésben egyébként nemcsak az Európai Unióban, hanem más piacgazdaságokban is megfigyelhető.

A tartós vállalati életképesség fogalma többé-kevésbé megfelel a fenntartható vállalkozás fogalmának, bár egyes területeken nyilvánvalóan vannak különbségek a hangsúlyokban. Ez a tanulmány a tulajdonosok és a menedzserek, illetve fóként az állam, pontosabban a gazdaságpolitika szemszögéból elemzi a magyar vállalati szférát a fenntarthatóság szemszögéból. 
Bár a tanulmány törekszik a holisztikus megközelítésmód érvényesítésére, azaz a téma komplex elemzésére, a feldolgozásban a gazdasági jelleg dominál, amennyiben a témát elsôsorban a vállalkozások és a szabályozás köré csoportosítva tárgyalja.

A fenntarthatóság a vállalkozások esetében egy lehetséges csoportosítás alapján három megközelítésben vizsgálható: számviteli szempontból, a vállalkozások múködése és a külső környezet alapján. A vállalkozások külsố környezetét egyrészt a versenyhelyzetet alakító tényezốk, másrészt a gazdasági szabályozás jellege határozza meg. A három tényező szorosan összefügg egymással.

\section{A fenntartható vállalkozás számviteli szempontból}

A fenntartható vállalat fogalma nem új, a számviteli alapelvek egyike a vállalkozás folytatásának elve, ami ha nem is felel meg teljesen a fenntartható vállalat fogalmának, szoros kapcsolatba hozható vele. A vállalkozás folytatásának elve azt mondja ki, hogy a vállalkozások belátható idốn belül nem szüntethetik meg vagy nem korlátozhatják jelentősen tevékenységüket, azaz a vállalkozók a belátható jövőben is fenn tudják tartani múködésüket, folytatni tudják tevékenységüket. Ha a vállalkozás folytatásának elve nem érvényesül, akkor a többi számviteli alapelv sem érvényesíthetô. Emellett sok más közvetett és közvetlen hatással is számolni kell (ilyen az adóbevételek és a foglalkoztatás csökkenése stb.).

Számviteli értelemben a fenntarthatóság egyik mércéje lehet az árbevétel és a költségek dinamikája és szerkezete. Az árbevétel növekedése önmagában is pozitív jelenségnek tekinthetô. A költségeken belül a bér- és anyagköltségek növekedése - egyéb tényezóktól eltekintve - arra engedhet következtetni, hogy a vállalkozás bővíti tevékenységét, ehhez növeli a foglalkoztatottak létszámát és fokozza a termelési inputok beszerzését. A bér- és anyagköltségek emelkedése ugyanakkor azt is jelentheti, hogy a vállalat múködésének, azon belül a termelésnek a hatékonysága romlik.

Fenntartható vállalatra utal a minőségbiztosítási rendszerek bevezetése is, különösen akkor, ha a cég a rendszert nem költségként számolja el, hanem eszközei közé teszi és amortizálja. Ez utóbbi ugyanis azt mutatja, hogy a vállalat hosszabb távon is fenn kíván maradni, a minőségbiztosítási rendszer leírásához ugyanis idôre van szükség. A fenntarthatóságot jelezheti még a környezetvédelemhez való hozzáállás, a cafeteria rendszer alkalmazása, a továbbképzés támogatása, illetve a vállalkozási tevékenység szolgálatába állítása. Mindez ugyanis a munkaeró hosszú távon történó megtartását és ösztönzését célozza.

Végül a vállalati eredmény szerkezete és az osztalékpolitika is tükrözi azt, hogy fenntartható vállalkozásról van-e szó vagy nem. A fenntartható vállalkozásoknak az üzemi eredménye a legnagyobb, azaz nem pénzügyi múveletekbôl és egyéb rendkívüli bevételekbốl termelnek nyereséget, hanem alaptevékenységükbő́l. Ami az osztalékpolitikát illeti, az a vállalat tekinthető fenntarthatónak, amely megtermelt nyereségét nem veszi ki, hanem újra befekteti, illetve a nyereség csekély hányadát fizeti ki osztalékként.

Általánosan elfogadottnak tekinthetố az a nézet, amely szerint a kis- és közepes méretú vállalkozások legfőbb problémája a tókehiány. Ennek ellentmond, hogy a bankok szerint középtávra, 5-7 éves futamidőre is van hitelkínálat. A szúk keresztmetszet nem a forráskínálat, hanem a vállalkozás, a vállalkozó hitelessége, a cég jövedelmezősége és a megtérülés. Így például alacsony a múszakszám, a folyamatos üzemtôl eltekintve a kis- és közepes méretú vállalatok 17 százalékában van két, és 8,8 százalékában három múszak, ami a tóke pazarló lekötésére és felhasználására utal. A tőkehiány ellen szól az is, hogy a tulajdonosok tókét vonnak ki a kis- és közepes méretú vállalkozásokból. 2004-ben a nyereséges cégek adózott eredménye 1851 milliárd forint volt, ebból 1025 milliárd forintot fizettek ki osztalékként. A veszteséges cégek 850 milliárd forint veszteséget mutattak ki. Ugyanakkor Magyarországon nemzetközi összehasonlításban (a Magyarországhoz hasonló egy főre jutó GDP-vel rendelkezô országokkal összevetve) magas a luxusgépkocsik, a luxusvillák, a külföldi ingatlanbefektetések száma és aránya. ${ }^{3}$ Ezek az adatok arra engednek következtetni, hogy a kis és közepes méretú vállalati szegmensben a vállalkozás folytatásának elve ugyan érvényesül, de sok jel utal a fenntartható vállalkozás elvének háttérbe szorulására. Ennek egyelốre nincs súlyosabb látható következménye, de a tôkekivonás folytatódása a KKV-szektorból hosszú távon gyengíti e vállalati kör pozícióit, gazdasági súlyát és stabilitását, aminek szélsôséges esetben súlyosabb makrogazdasági következményei is lehetnek.

\section{A fenntarthatóság a vállalkozások múködése alapján}

\section{A piacra való be-, illetve az onnan való kilépés és a vállalati életciklusok}

A vállalkozásokkal foglalkozó elméletek megosztottak a fenntarthatóság fogalmának a vállalati szférára történő alkalmazhatóságáról. A termék- és 
vállalaticiklus-elméletek a termékeket és a vállalatokat az élethez hasonlónak fogják fel, azaz új termékek, illetve vállalatok születnek, gyors ütemú felfutás után magas szinten történó stabilizálódás következik, majd az utolsó szakasz az abszolút vagy relatív hanyatlás, ami szélsőséges esetben a terméknek a piacról történő kivonásával, illetve a vállalat eltúnésével, kevésbé szélsôséges esetben marginalizálódásával jár. Az utolsó, hanyatló szakasz, illetve a termék és a vállalat eltúnése nem feltétlenül következik be, ennek ellenére a vállalkozások hosszú távú fennmaradására kevés a garancia, kevés vállalkozásnak sikerül. Elgondolkodtató, hogy például az 1896 óta számolt legismertebb amerikai Dow Jones tőzsdeindexet alkotó vállalatok az elmúlt több mint 110 évben kicserélódtek. Hasonló következtetésekre adnak alkalmat más megállapodott piacgazdaságok tôzsdeindexeinek összetételében bekövetkezett változások is.

A termék-, illetetve a vállalati életciklusoktól részben függetlenül elsôsorban az angolszász szakirodalomban kap nagyobb hangsúlyt a vállalatok keletkezése és megszúnése mint növekedési és termelékenységjavítási tényező. A vállalati dinamika (firm dynamics) definíciójába az új cégeket, azaz a piacra való belépést és a vállalatok piacról való kivonulását egyaránt beleértik. Az új technológiák gyakran új tơkében testesülnek meg. Ez a meglévő termelési telephelyek átalakítását, „átszerszámozását” teszi szükségessé, azaz a meglévő telephelyeken alkalmazkodni kell az új technológiákhoz, ami egyszersmind a munkaszervezés módosítását is maga után vonja. Mivel az újonnan létrejövő vállalatoknak nem kell végigmenniük ezen a folyamaton, ezért könnyebben képesek adaptálni az új technológiákat. Ebból az következik, hogy a növekedés elválaszthatatlan az új belépóktől, amelyek az elavultak, a kevésbé termelékenyek helyébe lépnek.

A meglévô szervezetek expanziója vagy zsugorodása, az új vállalatok létrejötte, illetve eltúnése az összes gazdasági szereplőre (vállalkozók, foglalkoztatottak, pénzügyi intézmények stb.) költségeket ró. E költségek nagyságrendjét a termék- és munkaerőpiacok intézményi rendje és szabályozása (például a vállalatalapításhoz szükséges adminisztráció, a csődtörvény, a munkaerő és a tőke vállalatok és szektorok közötti átcsoportosításával kapcsolatos elő́írások stb.) határozza meg. Ezzel részletesen a következő rész foglalkozik.

A vállalatoknak a piacra való belépése és az onnan történő kilépése számottevő mértékben járul hozzá a nemzetgazdasági szintú termelékenység növekedéséhez. Empirikus tapasztalatok alapján évról évre nagy számú vállalat lép be a piacra és távozik onnan. Az 1990-es évtized első felében a be- és kilépési ráta ${ }^{4}$ a legtöbb ország üzleti szektorában 20 százalék körül volt. Más szavakkal ez azt jelenti, hogy a vállalatok egyötöde egy adott évben vagy új belépő volt, vagy be fogja szüntetni tevékenységét. Ez a ráta óriási különbségeket mutatott minden egyes OECD-országban. Az NSZK-ban és Olaszországban a be- és kilépési ráta kisebb volt, mint az USA-ban, miközben az amerikai értéknél is magasabb volt az Egyesült Királyságban, és fóként Finnországban ${ }^{5}$.

A belépési és a kilépési ráták összehasonlíthatók. Ha a piacra való belépés hajtóereje adott iparágban a viszonylag magas nyereség, a kilépés pedig a túlnyomórészt alacsony nyereségességú szektorokra jellemzó, akkor a belépési és a kilépési ráták között negatív korreláció lenne. Ugyanakkor az empirikus tapasztalatok azt mutatják, hogy a belépési és a kilépési ráták szorosan korrelálnak az OECD-országok iparágaiban, méghozzá pozitív módon. Ez a korreláció különösen erôs akkor, amikor a be- és kilépési rátákat a foglalkoztatottsággal súlyozzák. Mindez arra enged következtetni, hogy minden idôszakban nagy számú új vállalat veszi át nagy számú elavult cég helyét anélkül, hogy ez a csere befolyásolná, pontosabban csökkentené a vállalatok számát és a foglalkoztatottságot a piacon bármely idôpontban.

Az OECD szakértối szerint a be- és kilépési ráták közötti szoros korreláció az iparágakon keresztül egyrészt annak az eredménye, hogy az új cégek kiszorítják a régieket, azok helyébe lépnek. Másrészt magas az újonnan jövốk bukási aránya életciklusuk első éveiben. A piacra újonnan belépó vállalatok túlélési valószínúsége az 1980-as évek végén meredeken esett. Az újonnan piacra lépố cégek 20-40 százaléka tûnt el az elsố két évben. Ezt követően a kilátások javulnak. Azok a cégek, amelyek az elsô két évet túlélik üzletágukban, 60-70 százalékos valószínúséggel a következô öt évet is túlélik. Ennek ellenére a piacon megjelenó összes cég 30-50 százaléka éli túl múködésének hetedik évét.

Az OECD vizsgálatai szerint a vállalatok túlélési aránya országonként eltérô. Az USA, Kanada és NagyBritannia esetében a feldolgozóipari vállalatok túlélési rátája kisebb, mint a kontinentális Nyugat-Európa országaiban. Fontos megjegyezni azt, hogy az alacsony túlélési ráta nem ad feltétlenül okot az aggodalomra. Egy cég megjelenése a piacon kísérletként is felfogható, és e folyamat természetéből adódik az, hogy a bukási arány magas. Ez különösen akkor van így, ha az új belépés a piacon lévő vállalatokat arra készteti, hogy növeljék hatékonyságukat és nyereségességüket. Sok szakértố szerint a nyereség-kockázat arányt figyelembe véve - nemcsak vállalati, hanem nemzetgazdasági szinten is - ez a legkevésbé költséges formája a vállalati szféra fejlődésének, az innovációt is beleértve. 
Az OECD keretében végzett kutatások arra utalnak, hogy a vállalatok piacra való belépésének és onnan történő kilépésének folyamata aránytalanul csekély számú foglalkoztatottat érintett. A bukás valószínúsége a vállalati múkködés korai szakaszában a kisvállalatok esetében nagyobb, míg a túlélő vállalatok nemcsak nagyobbak, hanem általános irányzatként gyorsabban is növekednek. Így a legtöbb országban a meglévő vállalatok mérete hasonló az újonnan belépó vállalatok méretéhez, miközben a túlélố vállalatok átlagos mérete gyors ütemben nô, hogy megközelítse az adott piacon múködő cégek átlagos méretét.

Empirikus tapasztalatok alapján a piacról történő kilépés ugyanakkor a legkisebb vállalatokra koncentrálódik. A gyors növekedés nyomán a túlélő vállalatok átlagos mérete az elsố hét évben megduplázódik. Az átlagos vállalati méretnek a piacra való belépést követô növekedése gyorsabb a szolgáltató szektorban, mint a feldolgozóiparban. A szolgáltató szektorban ugyanis eleve kisebb volt a piacra belépók átlagos mérete és nagyobb volt az új vállalkozások bukási aránya. A kis szervezetek bukása nagyobb, a túlélók méretének növekedése gyorsabb volt az USA-ban, mint a többi OECD-országban. Az elsố három évben e vállalati kör átlagos mérete háromszorosára nőtt. Ez arra enged következtetni, hogy az USA-ban kedvezőbbek a kis cégek piacra lépési lehetôségei, annak ellenére, hogy körükben magasabb a bukási arány. Az USA-ban a kis szervezetek kedvezóbb kísérletezési lehetóségei nem csekély mértékben magyarázzák azt, hogy az újonnan belépố vállalatok átlagos termelékenysége nemzetközi összehasonlításban szerény.

A be- és kilépési ráta értékeiben megfigyelhetô különbségek az egyes ágazatokban nem csekély mértékben vezethetốk vissza a termékciklusok eltéréseire. Egy új termék kereskedelmi bevezetése után kezdôdik a piacra való belépés kezdeti szakasza, amelyet egy fajta kiegyenlítődés követ, majd a vállalatok számának a csökkenése következik. Egy 46 termékre kiterjedő amerikai elemzés mintegy tízéves kezdeti belépési szakaszt talált, amit mintegy 5 éves zsugorodási szakasz követett ${ }^{6}$. Így a különbözố időpontokban megfigyelhetô piaci belépési hullámok a termékciklus kezdeti szakaszára engednek következtetni. Termékszintú információk azonban nem állnak rendelkezésre ennek a hipotézisnek igazolásához, csak iparági adatok vannak, azaz olyan adatok, amelyek minden egyes iparágban sok terméket és sok piacot foglalnak magukba.

Egy másik kutatás keretében egy 140.000 cégből álló minta vizsgálatára került sor az Egyesült Királyságban 1980 és 1992 között minden évben ${ }^{7}$. A kutatás fö következtetése az, hogy a kedvező cégdinamika, azaz az alacsony termelékenységü üzemek bezárása és termelékenyebb üzemek létesítése a teljes termelékenység javulásának a 90 százalékát magyarázta a szóban forgó időszakban. Az ezzel kapcsolatos gazdaságpolitikai következtetés az, hogy a vállalatok elötti piacra való belépési és az onnan való kilépési korlátokat meg kell szüntetni. Ez mindenekelőtt a versenypolitikára ró pótlólagos feladatokat.

Az OECD összehasonlító elemzése szerint azokban az iparágakban, amelyek szorosabb kapcsolatban vannak az információs és kommunikációs technológiával, a belépési összetevő nagyobb mértékben járul hozzá a munkatermelékenység növekedéséhez, mint a cégek kilépése ${ }^{8}$. Ennek viszont éppen az ellenkezóje igaz az érettebb ipari ágazatokban, ahol jelentősebb a vállalaton belüli növekedésnek és az elmaradt cégek kilépésének termelékenységi hatása. Végül a fenntarthatóság és a vállalati méretek között is szoros az összefüggés. Rendszerint annál relevánsabb a fenntarthatóság, minél nagyobb a vállalati méret.

A fenti gondolatmenetból többek között az a következtetés vonható le, hogy a vállalati fenntarthatóság nem abszolutizálható. A fenntartható vállalkozás fogalma nem alkalmazható a vállalati életciklustól függetlenül mindegyik vállalkozásra, a körülményektôl függetlenül nincs feltétlenül összhangban a gazdasági racionalitás, azon belül a hatékonyság követelményeivel. Semmiképpen nem indokolt ennek a követelménynek az érvényesítése az indulási szakaszban lévő vállalkozásokra, és korlátozottan lehetséges és célszerú a hanyatló vállalkozások esetében. A fenntarthatóság követelményének érvényesítése ebben a két vállalati kategóriában adott esetben csak állami támogatás mellett lehetséges, amit a piacgazdaságokban tiltanak. Állami támogatás nélkül is elképzelhetó, hogy a fenntarthatóság eróltetésének az ára - fóleg a hanyatló vállalkozásoknál - az alacsony hatékonyság, ami elôbb vagy utóbb veszteségekben jut kifejezésre.

A jelek szerint a vállalkozások fenntarthatóságának fogalma a klasszikus definíciókon és foglalkoztatási formákon alapul. Középpontjában azok a munkavállalók állnak, akik naponta megjelennek munkahelyükön munkavégzés céljából. Az atipikus foglalkoztatási formák, így például a távmunka nem tartozik bele. Ezeknek a terjedésével, amit az információs és kommunikációs technológiák fejlődése tesz lehetővé, azonban a foglalkoztatási szerkezet viszonylag rövid időn belül megváltozhat. Ráadásul a távmunkából adódó költségcsökkentés vállalati szinten forrásokat szabadít fel vagy teremt, ami adott esetben létszámbôvítésre használható. 


\section{A magyar vállalkozások és a fenntarthatóság}

Ami a vállalkozások természetét, ezzel összefüggésben múködését illeti, Magyarország gazdaságában meghatározóak a külföldi részesedésú vállalatok. Számuk mintegy 25 ezerre tehetó, de ennél jóval kisebb a magyar gazdaság fejlődését meghatározó külföldi nagyvállalatok száma. A Központi Statisztikai Hivatal adatai szerint külföldi részesedésú cégek állították elő 2001-ben a magyar hozzáadott érték 45 százalékát, rájuk jutott az értékesítés 49 százaléka és a beruházások fele. Jelenleg a külföldi részesedésú vállalatok adják a magyar kivitel több mint 80 százalékát. Ôk foglalkoztatják az ipari munkaerô egyharmadát. A vállalkozások természete szempontjából ezt a vállalatcsoportot nem vizsgáljuk, feltételezzük, hogy a vállalkozás folytatásának elve alapján tevékenykednek. A nagyvállalati szegmensben zömmel nagy múltú cégekról van szó, amelyek a fenntarthatóság követelményeivel összhangban múködnek. A külföldi nagyvállalatokéval megegyezik a hazai tulajdonú nagyvállalati szektor helyzete és múködése, ez a vállalati kör is megfelel a fenntarthatóság követelményeinek. A szúk keresztmetszetet a hazai mikro-, kis- és a középvállalkozások képezik, e vállalati szegmensben van a legtöbb probléma a fenntarthatósággal.

Magyarországon a Központi Statisztikai Hivatal adatai szerint 2004-ben 708 ezer vállalkozás múködött, miközben 1276 ezer regisztrált vállalkozás volt. A regisztrált és a múköőó vállalkozások közötti különbségből 578 ezer alvó vagy fantomcég adódik, ami önmagában is elgondolkodtató. Ezek az adatok csak a valamilyen vállalkozási formában múködô mezőgazdasági vállalkozásokat tartalmazzák, a kistermelőket nem.

A 708 ezer múködő vállalkozásból mindössze 10.636 vállalkozás foglalkoztatott 20-49 fốt, 5028 cég 50249 fő́t és 946 vállalat 250 fônél többet. A vállalkozások 97,7 százalékának 20 fónél kevesebb foglalkoztatottja volt. Ez a vállalatcsoport mikrovállalkozásokat, továbbá kis- és közepes méretú cégeket tartalmaz, a továbbiakban erre a körre vonatkozik a kis- és középvállalati szféra megjelölés.

A kis- és közepes méretú vállalkozások jelentôs része nem piaci alapon múködik, hanem kényszervállalkozás. Erre is utal az a körülmény, hogy 2004-ben a múködő vállalkozások kétharmadának nem volt bejelentett alkalmazottja. A vállalati struktúra alapján a fenntarthatóság fogalma mintegy 15-16 ezer vállalkozásra, azaz a múködô vállalkozások 2 százalékára vonatkoztatható Magyarországon nagyobb fenntartások nélkül, a többi vállalkozásra viszont csak erôs fenntartásokkal és árnyalással.
A reálgazdasági folyamatok szempontjából a kisés középvállalati szegmens a lényeges, a mikro- és az ál- vagy kényszervállalkozások csoportjában a fejlesztés és a növekedés egyáltalán nem kézenfekvő. Emellett a mikro- és a kényszervállalkozások nehézségek nélkül múködhetnek a kereskedelemben és nagyszámú szolgáltató ágazatban és alágazatban (ingatlan- stb. szolgáltatás), a dolog természeténél fogva nem indokolt tôlük exportot és kutatás-fejlesztési tevékenység folytatását várni.

A kis- és középvállalkozások a magyar GDP 45 százalékát állítják elő, miközben a magángazdaságban foglalkoztatottak 60 százaléka (több mint 1,5 millió fó) jut rájuk. E szektor volt az, amely az utóbbi 15 évben nettó foglalkoztatásbóvülést tudott produkálni. Ráadásul a kis- és középvállalati szektor foglalkoztatási szerkezete regionálisan sokkal kiegyenlítettebb, mint a nagyvállalatoké. A foglalkoztatási rátára gyakorolt hatás mind a Budapest-vidék, mind a vidéki régiók közötti különbség esetében kisebb eltérést mutat, mint a nagyvállalatoknál ${ }^{9}$. A kényszervállalkozások nagy száma miatt azonban az itt lévő munkahelyek sokkal instabilabbak, mint a nagy szervezeteknél.

A jelentôs foglalkoztatási funkció miatt a kis- és közepes méretú vállalatok kiemelkedő szerepet játszanak a lisszaboni stratégia foglalkoztatási céljainak megvalósításában (a foglalkoztatási ráta - a foglalkoztatottak aránya a gazdaságilag aktív népességben -70 százalékra történő emelése 2010-ig). A hazai kis- és középvállalati szektor termelékenységének nagyvállalatokéhoz viszonyított lemaradása nagyon jelentôs, lényegesen nagyobb az Európai Unióban tapasztalhatónál. A magyar kisvállalkozások nagyvállalatokhoz viszonyított termelékenysége mintegy a fele, a közepes vállalatoké pedig kétharmada az európai uniós átlagnak $^{10}$

A feldolgozóiparban különösen aggasztó a középvállalatok kis száma, ami ráadásul alig nőtt 2001 és 2004 között. Kiegyensúlyozatlan szerkezetre enged következtetni az a körülmény, hogy például a közel 50 gép- és berendezésgyártó nagyvállalat mellett mindössze 210 közepes méretú cég múködik. A villamosgép- és múszergyártás több mint száz nagyvállalata mellett csak 191 közepes méretú vállalat van. A vegyipar szerkezete is hasonló, 44 nagyvállalatra 59 közepes cég jut.

A keresetek is sajátos differenciálódást mutatnak, minél kisebb egy szervezet, annál alacsonyabb a kereset, ami viszont a fekete- vagy szürkegazdaság jelenlétére is utalhat. Egy 2003-ban készült tanulmány szerint az azonos ágazatban, hasonló vállalati méretek mellett a külföldi tulajdonú vállalatoknál két és félszer annyi a 
fizetés, mint a magyar cégeknél. A tốkeerôsebb külföldi hátterú vállalatok kisebb mértékben élnek az ,adóoptimalizálás" vagy adókikerülés lehetőségeivel, így a papíron minimálbéren történô vagy részmunkaidôs foglalkoztatással, illetve az alkalmazottjaik kényszervállalkozásba való terelésével. Egy 2002. évi osztrák felmérés szerint az egy foóre jutó bérköltségekben viszonylag kis különbség volt a kis- és a nagyvállalatok között. Az ezer főnél többet foglalkoztató vállalatok foglalkoztatottjainak keresete átlagosan 35 százalékkal haladta meg a kis szervezetekéit, ami összhangban van a normál piaci viszonyokkal. A vállalati méretekhez kötôdő különbség Magyarországon is 40 százalékon belüli. A határvonal a hazai és a külföldi vállalatok között van. Ezt nem csekély mértékben magyarázhatja az, hogy a gyengébb tókeellátottság és az alacsonyabb termelékenység miatt a hazai vállalkozások fennmaradását veszélyeztetné, ha a külföldi cégekre jellemzô magas keresetekhez kapcsolódó terheket is meg kellene fizetniük. ${ }^{11}$

A szektor sajátosságaiból és a gazdaságban elfoglalt szerepéból is következik, hogy a magyar kis- és középvállalkozások exportálóképessége alacsony, a kivitelnek mindössze 8-10 százalékát adják, tehát döntően a hazai piacon értékesítenek, ami - az exportorientált nagyvállalatoktól eltéróen - korlátozza növekedési lehetôségeiket. Emellett van bizonyos közvetett export, exportőr nagyvállalatoknak történő beszállításon keresztül.

A kis- és közepes méretú vállalatok árfolyamváltozásoknak való kitettsége kiemelkedô mértékú. A tranzakciós árfolyamkockázat, amelynek forrása konkrét üzlet, kevéssé jellemzó, tekintettel arra, hogy e szegmens vállalatai alig kapcsolódnak be a nemzetközi munkamegosztásba. A gazdasági kitettség, amely a devizaárfolyamok mozgása miatt a cég versenyképességében, illetve a cég értékelésében bekövetkező változás kockázata, akkor is jelentkezhet, ha a vállalatnak nincs semmilyen devizaügylete. Például a forint felértékelődése a dollárral vagy az euróval szemben olyan olcsóvá teheti a behozatalt, hogy a tisztán hazai piacra, hazai alapanyagból termelő vállalat is piacot veszíthet.

A magyar gazdaság sajátos ellentmondása az, hogy a foglalkoztatottak oroszlánrésze és a foglalkoztatási dinamika a nem vagy a fenntarthatóság követelményének kevésbé megfelelô vállalkozásokra jut, amelyek egyébként is „hajlamosak” adóelkerülésre, a fekete vagy szürkegazdaság „szabályainak” megfelelő múködésre. Ez jelentős kockázati tényező a lisszaboni stratégia foglalkoztatási céljainak teljesítése szempontjából.

\section{A vállalkozások külsố környezete}

A vállalkozások fenntarthatóságát a vállalkozások természetén túlmenően kiemelkedő mértékben érinti még a külső környezet, amely két részre bontható. Az első az általános versenykörnyezet, a második a szabályozási környezet. A kettố nem mindig választható el egymástól.

\section{Versenykörnyezet}

Mint ismert, Magyarországon az áruk, a szolgáltatások, a munkaerő és a tốke piaca többé-kevésbé liberalizált. Korlátozások annyiban vannak érvényben, amenynyiben azokat a közösségi jogszabályok megengedik, illetve lehetôvé teszik. A liberalizáció foka az áruimport és a pénz- és tốkepiac esetében a legnagyobb, míg a szolgáltatások külkereskedelmében és a munkaerőáramlásban még jelentősebb akadályok vannak.

Noha a magyar vállalkozások számára leglényegesebb piac, az árupiac, az importot is beleértve, teljes mértékben liberalizált, a verseny sajátos vonásokat mutat. Egy lehetséges megközelítésben az árupiacok, ezekhez kapcsolódóan a termelő vállalatok két nagy szegmensre bonthatók. Az egyik szegmenst a Magyarországra települt, exportbázis szerepkört betöltô, exportra termelő külföldi nagyvállalatok képezik. A dolog természetéból adódóan e szegmens termékei nem versenyeznek a hazai piacon. A verseny a megfelelő szakképzettségú és motiválhatóságú munkaeróért és a beszállítói megrendelésekért folyik. A másik szegmenst a hazai termékpiac képezi, amelyen az importált és a hazai előállítású termékek közötti verseny folyik, ez utóbbiak előállításában és értékelésében hazai és külföldi cégek egyaránt részt vesznek.

A magyar termékpiacokon nem a szabad versenyes, hanem az oligopolisztikus piaci szerkezet dominál, amelyet a nagyfokú vállalati koncentráció jellemez, amennyiben kis számú nagyvállalatra összpontosul a forgalom nagyobbik hányada. A közgazdasági elmélet bebizonyította, hogy az oligopol piacokon az árak hosszabb idốn keresztül stabilak. Ha egy cég emeli az általa forgalmazott termék vagy szolgáltatás árát, akkor a versenytársak e lépésre nem reagálnak áremeléssel, így az árat emelő cég piaci részesedése csökken. A cég vagy tönkremegy, vagy kénytelen újból mérsékelni az árat. Ha viszont egy vállalat árat csökkent, akkor olyan pusztító árverseny indul meg, ami egyik piaci szereplónek sem érdeke. Ezért az árak hosszabb időszakban viszonylag stabilak, amit a reálszféra oldaláról többek között a múszaki fejlesztés, illetve az azzal kapcsolatos termelékenységjavulás tesz lehetővé. Ezzel párhuzamosan a piaci verseny súlypontja az árakról más, nem 
ár jellegú tényezókre tevődik át. Az oligopolisztikus piacokon a nagyvállalatok az ár helyett a versenyképesség más összetevőire (kutatás-fejlesztés, innováció, minőség, védjegyek, reklám, termékdifferenciálás stb.) helyezik a hangsúlyt.

Az oligopolisztikus piacokon igen erôs a nagyvállalatok törekvése arra, hogy a hosszú távú árstabilitásból adódó, az áron kívüli versennyel összefüggő́ következményeket a kis- és középvállalkozásokra terhelje. Ilyen a kis- és középvállalatokkal szemben alkalmazott hoszszú (gyakran több hónapos) fizetési határidô, a kemény áralku, aminek eredményeként alacsony a beszállítók áruinak átvételi ára, a kereskedelemben az ún. polcpénz fizetésének kikényszerítése, az árengedmények és egyéb akciók finanszírozási terheinek a kis- és középvállalati beszállítókra való áthárítása stb. Az oligopolisztikus piacokon gyakori a domináns nagyvállalatok részéról az erőfölénnyel való visszaélés és sok más versenyellenes magatartási forma. A hosszú fizetési határidőból adódó problémákat az érintett vállalatok faktorálással próbálják meg áthidalni. Piaci információk szerint például az építőiparban egyes nagyvállalatok nem járulnak hozzá ahhoz, hogy kis- és közepes méretú beszállítóik faktoráltathassák számláikat.

Az oligopolisztikus piacok sajátosságait bemutató eszmefuttatásból az következik, hogy egyrészt a nagyvállalatok a piaci verseny árakon kívüli területein hajlamosak az erófölénnyel való visszaélésre. Másrészt a belsố múködésben definiált fenntarthatóság költségeit vagy azok jelentős részét többek között a kis- és középvállalati beszállítóikra terhelik.

A tapasztalatok alapján az Európai Gazdasági Térség, illetve tágabb értelemben a páneurópai kumulációs övezet országaiban bejegyzett, Magyarországon megtelepedett termelóvállalatok rendszerint magukkal hozzák beszállítóikat (vagy azok maguktól is megjelennek), ezáltal szúkítik a hazai kis- és középvállalkozások mozgásterét a különféle együttmúködési hálózatokban való részvételben. Egyébként is általános tapasztalat, hogy nehéz transznacionális nagyvállalatok beszállítójává válni, a hazai kis- és közepes méretú cégek jelentős része nem tud eleget tenni a transznacionális cégek által támasztott követelményeknek. Valamivel kedvezóbb a helyzet az Európai Gazdasági Térségen, illetve a páneurópai kumulációs övezeten kívüli országokban bejegyzett vállalkozások esetében, amelyek magyarországi telephelyei a szigorú származási szabályok miatt csak a helyi hozzáadottérték-tartalom bizonyos szintjének elérése esetén exportálhatják itt készített termékeiket vámmentesen az EU-ba, tehát jobban érdekeltek a magyarországi beszállítói kapcsolatok fejlesztésében.
A hazai tulajdonú kis- és középvállalati szektor egyébként is meglehetősen fragmentált, gyengék mind a vertikális, mind a horizontális együttmúködési formák és hálózatok, ami szúkíti a KKV-k fejlődési lehetóségeit. Ezen a helyzeten enyhít a klaszterek utóbbi idôben tapasztalható elterjedése.

\section{Szabályozási környezet}

Ha feltételezzük, hogy a vállalkozó ért a racionális gazdálkodáshoz és józan kockázatvállaló képességgel is rendelkezik, akkor a piaci és gazdaságpolitikai feltételek döntik el azt, hogy a vállalkozás életképes lesz-e vagy sem. A gazdasági szabályozás a vállalkozásalapítás és a vállalati múködés jogszabályokhoz kapcsolódó költségein keresztül fejti ki hatását, és alakítja a vállalkozások fenntarthatóságát. A vállalkozásalapítás, illetve vállalkozásindítási költségek, amelybe a vállalkozásalapítás idôigénye is beleértendő, Magyarországon nem jelentős, nem jelent akadályt a vállalkozásalapítás előtt. Egyéni vállalkozás induló tôke nélkül, betéti társaság minimális (szimbolikus) tókével indítható, a korlátolt felelôsségú társaság alapításának minimális tốkeigénye 3 millió forint. Ez utóbbi összeg nagyobb nehézség nélkül elôteremthetô. Ráadásul a kormány igyekszik tovább mérsékelni a vállalkozásalapítás költségeit, így például tervezi a korlátolt felelôsségú társaságok alaptôke-követelményének mérséklését, mondván, hogy nem az államnak, hanem elsősorban a piacnak kell meghatároznia az induló feltételeket.

Szoros korreláció figyelhetô meg az alapítási költségek és a vállalati méretek között. Minél kisebb a vállalkozás, annál kisebbek az alapítási költségek. A mikro- és a kisvállalkozások alacsony és csökkenô alapítási költségei arra engednek következtetni, hogy az egymást követô kormányok kiemelt jelentôséget tulajdonítottak a foglalkoztatás növelésében a KKV-szektornak.

Ugyanakkor megjegyzendő, hogy nemzetközi öszszehasonlításban a vállalkozásalapítás költsége és idôigénye Magyarországon számottevô. A Világbank Doing Business adatbázisa ${ }^{12}$ alapján Magyarország 2005-ben a 80., 2006-ban a 87. helyen állt a világ 175 országát tartalmazó rangsorban.

A vállalkozásalapítástól elválaszthatatlan a vállalkozások megszúnése. A megállapodott piacgazdaságokban a befektetók és a vállalkozók akkor fektetnek be új vállalkozásba, ha megfelelố garanciák vannak arra, hogy nagyobb nehézség és veszteségek nélkül ki tudják vonni tókéjüket a vállalkozásból annak sikertelensége esetén. A piacról való kilépés feltétele a fejlett tốkepiac, ebben az esetben nem a termeló- és egyéb eszközök, hanem a tulajdonosi jogokat megtestesítő 
értékpapírok cserélnek gazdát. A piacról való kilépés a legegyszerúbb a nyílt részvénytársaságok esetében. Magyarországon az egyébként is kis számú részvénytársaságon belül a zárt alapításúak dominálnak, ezek részvényeinek értékesítése nehezebb, mint azoké, amelyek részvényeit bevezették az értéktôzsdére. A korlátolt felelősségú társaságok törzsbetéteinek és a jogi személyiséggel nem rendelkezố társaságok és az egyéni vállalkozások üzletrészének értékesítése nehéz. Az esetek nagy részében nem marad más hátra végelszámolás esetén, mint az eszközök értékesítése. A Világbank Doing Business adatbázisa szerint Magyarországon igen költség- és idôigényes a vállalatok felszámolása, Magyarország 2005-ben az 57., 2006ban a 48. helyen állt a nemzetközi rangsorban.

A vállalkozások folyamatos múködési költségei ugyanakkor magasak, illetve jelentôsen nôtttek az utóbbi években. A mikro- és a kisvállalkozás keretében az önálló foglalkoztatás jórészt a munkaviszony keretében történô nem önálló foglalkoztatást helyettesíti. Az adott adózási feltételek között az önálló foglalkoztatás részben nem önálló foglalkoztatást váltott, illetve vált ki, illetve a foglalkoztatás növekményének jelentős részét adja.

Sajátos ellentmondás ugyanakkor az, hogy bár a mikro- és kisvállalkozások keretében történő önálló foglalkoztatás rövid távon olcsóbb, mint a munkaviszony keretében történó foglalkoztatás, ez csak bizonyos kritikus nagyságrendek felett lehetséges, illetve kifizetődő. Először is az ügyvezetố bére 2007-ben havi 131.000 forint, amit ha nem is fizetnek ki, akkor is ez után kell fizetni a járulékokat. Erre rakódik rá munkaadói teherként 27.510 forint nyugdíjbiztosítási, 10.480 forint egészségbiztosítási járulék, 1965 forint szakképzési és 1950 forint egészségbiztosítási hozzájárulás, ami összesen 172.905 forint havonta, éves szinten pedig 2.074.860 forint. Ehhez adódik még hozzá a bankköltség, amelynek egy része a forgalomtól függ, éves átlagban 50.0000 forinttal lehet kalkulálni és a könyvelési díj, amely minimum 2.400.000 forint évente. Mindezt összeadva évente minimálisan 2,4-2,5 millió forint, de inkább 3 millió forint múködési költség adódik egy egyéni vállalkozás vagy egy betét társaság számára. Ez nem tartalmazza a múködéshez szükséges eszközök, anyagok stb. árát és a telephely bérleti díját és rezsiköltségeit.

Sajátos ellentmondás ugyanakkor az, hogy bár a mikro- és kisvállalkozások keretében történő önálló foglalkoztatás a bevételek egy részének „elköltségelése” miatt rövid távon olcsóbb, mint a munkaviszony keretében történó alkalmazás, ez csak bizonyos kritikus nagyságrend felett lehetséges, illetve gazdaságos. Mivel a nagyvonalú költségelszámolás fölött bizonyos határok között az APEH szemet huny, ezért az „elköltségelés” lehetősége burkolt adókedvezménnyel egyenértékú. Ennek persze hosszú távú következményei beláthatatlanok. Például a minimálisan megkövetelt járulékfizetés miatt alacsony a nyugdíj, mert a nyugdíj nagysága a minimálbér nagyságához igazodik stb.

Ha piacszerúen múködő vállalkozásokról van szó, tehát nem munkaviszonyt helyettesít a mikro-, illetve a kisvállalkozás, akkor a minimálisan évi 2,5-3 millió forint múködési költséget üzleti tevékenységból kell kitermelni. Kereskedelmi vállalkozás esetében, 20 százalékos árrést feltételezve, 12,5-15 millió forint éves forgalmat kell elérni, miközben az eladásra vásárolt árut is finanszírozni kell. Termelővállalkozás esetén az anyagköltség helyettesíti az eladott áruk beszerzési költségét. Az anyagi javakat elóállító szférában azzal is kell számolni, hogy az optimális üzemméret elérése sok ipari ágazatban és alágazatban meghaladja a kis- és középvállalkozások lehetôségeit. A szolgáltató szférában értelemszerúen kisebbek ezek a korlátok.

Pótlólagos új munkaerô alkalmazásának költsége éves szinten kétmillió forint, ami az árbevétel tízmillió forinttal történő bővítését teszi szükségessé 20 százalékos kiskereskedelmi árrés vagy üzemi eredmény feltételezésével. A minimálbér kétszeresét alapul véve ennek legalább ötszörösével kell növelni az árbevételt a létszám egy foovel történő emelése érdekében. A kis- és a középvállalatok növekedését, fenntarthatóvá válását nehezíti, hogy amíg a folyamatos, kismértékủ teljesítménybővülés egy bizonyos pontig konstans munkaeró-állomány mellett is elképzelhetô, addig új munkaerő beállításához lökésszerú árbevétel-növekedésre van szükség. Ez a kisvállalkozások középvállalkozássá válásának, illetve a középvállalati szektor megerősödésének legfốbb akadálya. A szabályozási környezet gyakori változásai mellett mindennek valószínúleg fontos szerepe van abban, hogy a középvállalkozások megtermelt nyereségük nagy hányadát osztalékként fizetik ki, a nyereség kis részét forgatják vissza a vállalkozásba.

A Világbank adatbázisa szerint a munkaerô alkalmazásában Magyarország 2005-ben a 89., 2006-ban a 90. helyen állt, azaz nemzetközi összehasonlításban meglehetôsen sok nehézséggel jár a munkaerô alkalmazása. Ez a mutatószám nem a bérekre, illetve tágabb értelemben a munkaeróköltségekre vonatkozik, hanem a munkaerôpiac szabályozására. Mindez korlátozza a foglalkoztatás bővítését. A minimálbér kétszerese utáni járulékfizetési kötelezettség a feketegazdaságba, fekete-foglalkoztatásba való menekülést erôsíti.

A kérdés az, hogy egyrészt van-e tömeges kereslet a liberalizált magyar piacon ilyen áru- és szolgáltatás- 
mennyiség iránt, másrészt képesek-e, ha igen, milyen kondíciók mellett belépni a kis- és közepes méretú vállalkozások az oligopolisztikus jellegú hazai piacra. Nagyszámú jel szerint a kereslet és a piacra való belépés korlátai jelentik a legszámottevóbb akadályt a kis- és közepes méretú vállalkozások expanziója elótt. A magyar gazdaság jelenlegi szerkezetében semmilyen garancia nincs arra, hogy a gazdasági növekedés exportexpanzión és a beruházások növekedésén alapuló gyorsulása vagy az EU-források beáramlása a KKVszektor vállalatainak termékei és szolgáltatásai iránti keresletet is jelentôs mértékben dinamizálja.

Az életképességnek három tartománya különböztethetố meg: az életben maradási képesség, amely csupán a költségek megtérülését és a tulajdonos megélhetését biztosítja, a lépéstartási képesség, amikor a megtermelt nyereség elegendő a megszerzett piaci pozíciók megtartására, végül az expanziós képesség, amikor a vállalat rendszeresen számíthat az elvárt haszonszintet érezhetôen meghaladó jövedelmezőségre. ${ }^{13} \mathrm{E}$ megközelítésben legalább ötszázezer szervezetre az életben maradási képesség a jellemző, míg kevés a lépéstartási, még kevesebb az expanziós képességgel rendelkező magyarországi vállalkozás.

A közel hétszázezer mikro- és kisvállalkozás ráadásul irdatlan tranzakciós költséget generál a nemzetgazdaság egésze számára, és megoldhatatlan feladat elé állítja az APEH-et. ${ }^{14} \mathrm{~A}$ jövedelemeltitkolás lehetôsége lehetetlenné teszi, de legalábbis akadályozza a kis- és középvállalatok közötti kooperációt. Emiatt a szektor banki és tốkepiaci finanszírozása is nehéz.

Ráadásul az egyéni és családi megtakarításokból induló kisvállalkozások néhány millió forint alaptốkéje nem elegendő technológiai korszerúsítésre és piaci innovációra. Ezek a cégek nemigen tudják előteremteni azt a 20-40 millió forintot sem, amely a kisvállalati méretekben is a standard minőségú, rugalmas árutermelés megalapozását célzó beruházás forrásigénye.

A magyar vállalati szféra sajátos vonása az, hogy a hazai és fóleg a külföldi nagyvállalatok fenntarthatóságát különféle legális és legitim, a közösségi jogszabályokkal összhangban lévô adókedvezmények biztosítják. A mikro- és kisvállalkozások múködéséhez szintén kiemelkedô mértékben járulnak hozzá az adózással kapcsolatos szabályozási tényező́k, amilyen az EVA és az EKHO. Emellett ez a vállalati szegmens a leginkább érintett a fekete- és szürke-gazdaságban. A legrosszabb helyzetben a középvállalkozások vannak, amelyek nemigen támaszkodhatnak adókedvezményekre, miközben az adóelkerülés, a fekete vagy a szürke gazdaságba való bekapcsolódás lehetőségei is korlátozottak.

\section{Következtetések, ajánlások}

A fenntartható vállalkozás fogalma a megállapodott, fejlett piacgazdaságokban alakult ki, az ott honos feltéteket tükrözi. Elsősorban „minőségi” jellegú fogalom, a meglévô, a tapasztalatok alapján meglehetôsen stabil vállalatszervezeti rendszerre, struktúrára, illetve az azt alkotó, a gazdaságba erôsen beágyazódott vállalatokra épül. Ráadásul a Nemzetközi Munkaügyi Szervezetben hajlamosak egy-egy fogalmat, jelen esetben a vállalkozások fenntarthatóságát „túldimenzionálni”, adott esetben mások (például az innováció, a foglalkoztatás, a versenyképesség stb.) rovására. Emellett a vállalkozások fenntarthatóságát az ILO - nyilvánvalóan feladatából adódóan is - a munkavállalók szempontjából, a munkavállalói érdekeket hangsúlyozva kezeli.

Magyarországon és a többi közép- és kelet-európai országban a fenntartható vállalkozás fogalmát inkább „mennyiségi” szempontból célszerú vizsgálni, mert sok okból kifolyólag nagyszámú olyan vállalkozás van, amelyre ez a követelmény nem érvényes. Következésképpen a gazdaságpolitika feladata is inkább „mennyiségi” jellegú, azaz azon vállalkozások számának a növekedését célszerú serkentenie, ahol a fenntarthatóság követelménye érvényesíthetô.

A fenntartható vállalkozás fogalmát differenciáltan és árnyaltan célszerú értelmezni, a vállalati fenntarthatóság nem abszolutizálható. Ebból az is következik, hogy a megállapodott piacgazdaságokban is szem elôtt kell tartani bizonyos „mennyiségi” összefüggéseket. A fogalom alkalmazásakor figyelembe kell venni a termékek és a vállalatok (egymással szorosan összefüggó) életciklusát és a vállalati méretet. A fogalom a körülményektól függetlenül nincs feltétlenül összhangban a gazdasági racionalitás, azon belül a hatékonyság követelményeivel. Semmiképpen nem indokolt ennek a követelménynek az érvényesítése az indulási szakaszban lévő vállalkozásokra és korlátozottan lehetséges és célszerú a hanyatló vállalkozások esetében. Az életciklus hanyatló szakaszában lévő vállalatok esetében még az állami támogatás iránti igény is felvetődhet a fenntarthatóság követelményére hivatkozva. A vállalatok szubvencionálása ellentmond a piacgazdaság elveinek és a közösségi jogszabályoknak. Az induló vállalkozásokkal szemben is indokolatlan a fenntarthatóság követelményének alkalmazása. Általánosítva: a vállalkozásfenntarthatóság követelményének érvényesítése nem mehet a mikro- és a makrogazdasági versenyképesség rovására.

Mindezek alapján a fenntarthatóság követelménye egyrészt erkölcsi imperativusként (a Kant-féle sollen értelmében) alkalmazandó a vállalkozásokra a vállala- 
ti életciklustól függetlenül, másrészt a fenntarthatóság fogalma a növekedés és az érettség szakaszában lévő vállalkozások számára releváns. Az erkölcsi imperativus megjelenik a vállalkozás folytatásának számviteli elvében, amely implicite minden vállalkozással szemben tartalmazza a fenntarthatóság követelményét. A vállalatok életciklus alapján történó besorolása a gyakorlatban elég nehéz. Ezért pragmatikus okokból a kezdô vállalkozásokat célszerú figyelmen kívül hagyni.

A termékek, illetve a vállalatok életciklusán alapuló megközelítés a versenyre, pontosabban a vállalatok közötti verseny következményeire koncentrál. Mondanivalója az, hogy ha a nem hatékony vállalkozások kilépnek a piacról és helyüket hatékony vállalkozások foglalják el, akkor ez javítja az erőforrások allokációját, ezáltal a mikro- és a makrogazdasági hatékonyságot, ezen keresztül a társadalmi jólétet.

Ehhez kapcsolódó fontos következtetés, hogy a vállalatok piacról való kilépése, illetve a piacra való belépése megfeleló rugalmasság esetén nem érinti a munkavállalókat, a magas vállalati dinamika nem feltétlenül, sót a tapasztalatok alapján egyáltalán nem növeli a munkanélküliséget. Megkockáztatható az az állítás is (bár ez bizonyításra szorul), hogy a magas vállalati dinamika nettó hatása a foglalkoztatottság növekedése. A munkahelyek megtartását tehát nem minden esetben a fenntartható vállalat szolgálja a legjobban. Amíg a fenntartható vállalkozás középpontjában a munkavállalók szempontjából a konkrét munkahelyek stabilitása áll, addig a vállalati dinamika általában a munkahelyek stabilitását, illetve a foglalkoztatottság növekedését eredményezi makrogazdasági szinten, esetenként nagy kilengésekkel.

A fenntartható vállalkozás fogalma mögött az a feltételezés húzódik meg, hogy maga a vállalat képes a megváltozott környezethez történô alkalmazkodásra, miközben a munkavállalók szerepe ebben másodlagos. A vállalati dinamika jelentőségét hangsúlyozó nézetek ezzel szemben a vállalati megszúnésekkel és az új vállalatalakulásokkal összefüggésben nagyobb alkalmazkodási költségekkel számolnak, miközben a munkavállalók rugalmassága is kiemelkedó jelentôségre tesz szert a modellben.

Mérlegelendő, hogy a magyar viszonyok között a fenntartható vállalat fogalma mellett nem kellene-e a fenntartható munkahely fogalmát is bevezetni, illetve hangsúlyozni. A munkavállalók szempontjából ugyanis reális alternatíva az önálló foglalkoztatás (mikrovállalkozás keretében) és a munkavállalás (valamilyen vállalkozásnál). E megközelítésben nem a vállalkozás jellege, hanem magának a munkahelynek a biztonsága és stabilitása a fontos, bár kétségtelen, hogy a fenntartható vállalkozások munkahelyei is nagy valószínúséggel fenntarthatóak. A fenntartható munkahely fogalma inkább olyan verseny- és szabályozási környezet kialakítását célozza, amelyben tartósan stabil munkahelyek léteznek, szigorúbb értelmezésben a stabil munkahelyek száma folyamatosan nô.

Végül az önmagában is és nemzetközi összehasonlításban is egyaránt magas munkanélküliségi ráta felveti azt a kérdést, hogy Magyarországon és a többi középés kelet-európai országban nem kellene-e szigorúbban értelmezni a fenntartható vállalkozás fogalmát. Ez az értelmezés annyival több az ILO-énál, hogy a munkahelyek számának lehetôség szerinti bóvítésének követelményét is magában foglalja. Ezzel szemben a legfóbb ellenérv az, hogy ilyet nem lehet eloóíni.

Magyarországon a vállalkozások túlnyomó részére (legalább ötszázezer szervezetre) az életben maradási képesség a jellemzố, míg kevés a lépéstartási, még kevesebb az expanziós képességgel rendelkező vállalkozás. Ezen a helyzeten nehéz változtatni, a gazdaságpolitika mozgástere meglehetôsen szúk.

A fenntarthatóság követelménye érvényesül a külföldi részesedésú és a hazai tulajdonban lévố nagyvállalatok többségében. Általában is megalapozott az a következtetés, hogy a külföldi részesedésû́ nagyvállalatok kiemelkedő szerepet töltöttek be a fenntarthatóság követelményének érvényre juttatásában a magyar vállalati szférában. Az eddigi tapasztalatok legalábbis arra utalnak, hogy a legtöbb vezető külföldi nagyvállalat tartósan telepedett le Magyarországon. A hazai szabályozási és a külföldi versenykörnyezetben bekövetkezô változások nyomán azonban módosulhatnak múködési feltételeik, egyesek közülük megfontolhatják a Magyarországról való kivonulást, mint ahogy erre nem egy példa volt már az utóbbi években.

A gazdaságpolitikának célszerú folyamatosan ellensúlyoznia a külföldi cégek külső környezetének magyar szempontból hátrányos következményeit annak érdekében, hogy itt tartsa, ső́t tevékenységük további bővítésére ösztönözze a külföldi nagyvállalatokat. Célszerú még a vállalati fenntarthatóság követelményeinek eleget tevố külföldi nagyvállalatok magyarországi közvetlen beruházásainak további ösztönzése.

A kialakult vállalatszerkezet sajátosságai miatt a magyar gazdaságpolitikával szemben a fó kihívás nem a fenntarthatóság erôsítéséhez kapcsolódik, hanem az erőforrásoknak és a foglalkoztatásnak a fenntartható vállalkozásokhoz történó áttereléséhez a nem fenntartható szegmensból. Itt tehát egy közvetett, átkaroló stratégiáról van szó. Ez egyébként teljes mértékben összhangban van a fekete- és a szürkegazdaság viszszaszorítására, kifehérítésére irányuló kormányzati tö- 
rekvésekkel. Ezzel kapcsolatban felvethetô a vállalatszervezeti rendszerre vonatkozó kormányzati stratégia kérdése. A fenntartható vállalkozás követelményének érvényesítésével a nagyvállalatok, szervezetek preferálásán alapuló stratégia van jobban összhangban.

A hazai és a külföldi nagyvállalati szféra a belsố viszonyokat tekintve összességében megfelel a fenntarthatóság követelményének, miközben egyáltalán nem biztos, hogy a partnereivel szemben is érvényesíti ezt az alapelvet. Ez lehet tudatos cselekvés, az erőfölénynyel való visszaélés révén, de adódhat egyszerúen az oligopolisztikus piaci szerkezet sajátosságainak kihasználásából, amikor a nagyvállalatok a kis- és közepes méretú beszállítóikra hárítják piaci versenyképességük fenntartásának költségeit. A kormány, pontosabban a Gazdasági Versenyhivatal feladata az erôteljes fellépés a versenyt korlátozó vállalati magatartással és az erőfölénnyel való visszaéléssel szemben.

A vállalkozásösztönzésen belül súlypontváltást célszerú végrehajtani. Eddig a vállalkozásösztönzésen belül az új vállalkozások alapítása kapott hangsúlyt, a múködő vállalkozások problémái háttérbe szorultak. Célszerú és kívánatos a múködő vállalkozásokra koncentrálni, ezen belül a célrendszer középpontjába egyrészt a közepes méretú vállalkozásokat, másrészt az e vállalati szegmens fennmaradásához, stabilizálásához, illetve bővüléséhez szükséges szabályozási és egyéb feltételek biztosítását, illetve javítását célszerú állítani. A kérdés az, hogy konkrétan hogyan. A kormány deregulációs programja kétségtelenül mérsékelni fogja általában a vállalkozások, különösen pedig a kis- és középvállalatok adminisztrációs költségeit, de a fenntarthatóság vázolt problémáin nem javít érdemben. Némi javulást eredményezhet az Új Magyarország Fejlesztési Tervben a kis- és középvállalkozások versenyképességének javítására allokált források felhasználása 2007 és 2013 között. A fejlett piacgazdaságokban eredményesen alkalmazták a bérszubvenciót, amikor az állam az elóre meghatározott feltételeknek eleget tevő vállalatok helyett fedezte az újonnan beállított munkaerő bérjárulékainak egy részét. $\mathrm{E}$ mögött az a megfontolás húzódott meg, hogy a bérszubvenció társadalmi költségei kisebbek, mint a munkanélküliségi segélyé. Magyarországon az ehhez hasonló konstrukció nem bizonyult túlságosan sikeresnek, miközben a bérekre rakódó munkavállalói járulékok további erôteljes mérséklése az államháztartás egyensúlyi korlátaiba ütközik.

A probléma piackonform megoldása azért nehéz, mert a kis- és középvállalati szektor rendszerint ott sikeres, ahol erőteljes az állami támogatásuk. Egyre több szakértő hívja fel például a figyelmet arra, hogy Né- metországban a kis- és középvállalati szektor agyontámogatott, rejtett és kevésbé rejtett formában, oly módon, hogy a szubvenciók nincsenek ellentmondásban a közösségi jogszabályokkal. Magyarországon erre már csak a költségvetés helyzete miatt sincs mód.

Végül megfontolandó a „Fenntartható vállalkozás” mozgalom és védjegy bevezetése. A javaslat lényege a fenntartható vállalkozás követelményeinek összefoglalása, és a mozgalomhoz vagy védjegyhez történó csatlakozás lehetőségének felajánlása önkéntes alapon a magyarországi vállalkozásoknak. Adott esetben ezt a javaslatot az ILO-konferencián is fel lehetne vetni.

\section{Lábjegyzet}

1 A tanulmány a Szociális és Munkaügyi Minisztérium Európai Integrációs és Nemzetközi Főosztálya megrendelésére a Nemzetközi Munkaügyi Konferencia 96. ülésszakán részt vevő magyar küldöttség számára készült, és a fenntartható vállalkozások fejlődésének előmozdítása címú napirendi ponthoz kívánt támpontokat adni.

2 International Labour Office, Geneva: The promotion of sustainable enterprises. International Labour Conference, 96th Session, 2007, Sixth item on the agenda. VI. oldal. http://www.ilo.org/ public/english/standards/relm/ilc/ilc96/pdf/rep-vi.pdf

3 Az adatok forrása: Reszegi László: Kis- és középvállalatok hatékonysága. Figyelő, 2006. augusztus 10-16., 50. oldal.

${ }^{4}$ A belépési rátát úgy számolják, hogy adott évben az újonnan belépô cégek számát elosztják a piacon lévő és az újonnan belépő vállalatok összegével. A kilépési rátát úgy kapjuk meg, hogy az egy adott évben a piacról kilépó cégek számát elosztjuk az előzó évben a piacon lévő cégek számával.

${ }^{5}$ E rész forrása: Productivity and firm dynamics: evidence from microdata. OECD Economic Outlook, 2000., Párizs, 209-223. oldal.

${ }^{6}$ Gort, M. - Klepper, George: Time paths in the diffusion of product innovation. Economic Journal, Vol. 92, 1982, No. 3.

${ }^{7}$ Disney, Richard - Haskel, Jonathan - Heden, Ylva: Restructuring and Productivity Growth in UK Manufacturing. Centre for Economic Policy Research, Discussion Paper 2463, 2000. május.

${ }^{8}$ Productivity and firms dynamics: evidence from microdata. OECD Economic Outlook 2000, Párizs, 209-223. oldal.

9 Magyar Köztársaság Kormánya: A kis- és középvállalkozások fejlesztésének koncepciója. A kormány 2007. február 7-én elfogadta. Budapest, 6. oldal. http://www.gkm.gov.hu/data/ cms1193305/kkv_fejl.pdf

${ }^{10}$ GKM-OM-IHM (2003): Gazdasági Versenyképesség Operatív Program 2004-2006, Budapest, április 25., 24. oldal. http:// www.nfh.gov.hu/xindex $2 . h t m ? \mathrm{p}=0 \& \mathrm{t}=2 \& \mathrm{i}=1904$

${ }^{11}$ Szürkegazdaság: ezermilliárdos lyuk az államkasszában. Népszabadság, 2005. december 10., 12. oldal.

$12 \mathrm{http} / / / \mathrm{www}$.doingbusiness.org/ExploreEconomies/Default. aspx?economyid $=87$

13 Kozma Ferenc: A kis- és középvállalkozások Magyarországon. Alma Mater (a Budapesti Gazdasági Fóiskola Kereskedelmi Vendéglátóipari és Idegenforgalmi Főiskolai Kara folyóirata) 5. szám, 2003, 44-45. oldal.

${ }^{14}$ Mihályi Péter: Közteherviselés - ma és holnapután. Élet és Irodalom, 2005. szeptember 16., 6. oldal. 


\section{Felhasznált irodalom}

A kis- és középvállalkozások fejlesztésének koncepciója (2007). Magyar Köztársaság Kormánya február 7-én elfogadta. Budapest, 6. oldal. http://www.gkm.gov.hu/ data/cms1193305/kkv_fejl.pdf

Disney, Richard - Haskel, Jonathan - Heden, Ylva (2000): Restructuring and Productivity Growth in UK Manufacturing. Centre for Economic Policy Research, Discussion Paper 2463

GKM-OM-IHM (2003): Gazdasági Versenyképesség Operatív Program 2004- 2006, Budapest

Gort, M. - Klepper, George (1982): Time paths in the diffusion of product innovation. Economic Journal, Vol. 92, No. 3.

International Labour Office, Geneva (2007): The promotion of sustainable enterprises. International Labour Conference, 96th Session, Sixth item on the agenda
Reszegi László (2006): Kis és középvállalatok hatékonysága. Figyelő, augusztus 10-16.

Productivity and firm dynamics: evidence from microdata. (2000): OECD Economic Outlook, Párizs, 209-223. oldal.

Kozma Ferenc (2003): A kis- és középvállalkozások Magyarországon. Alma Mater (a Budapesti Gazdasági Fốiskola Kereskedelmi Vendéglátóipari és Idegenforgalmi Fóiskolai Kara folyóirata) 5. szám, 44-45. oldal.

Mihályi Péter (2005): Közteherviselés - ma és holnapután. Élet és Irodalom, szeptember 16., 6. oldal. http:// www.doingbusiness.org/ExploreEconomies/Default. aspx? economyid $=87$

Szürkegazdaság ezermilliárdos lyuk az államkasszában (2005):. Népszabadság. december 10., 12. oldal.

Cikk beérkezett: 2007. 5. hó

Lektori vélemény alapján átdolgozva: 2007. 7. hó

\section{KEDVES OLVASÓ!}

NE FELEJTSE EL MEGÚJÍTANI ELÖFIZETÉSÉT EZ ÉVRE IS! 